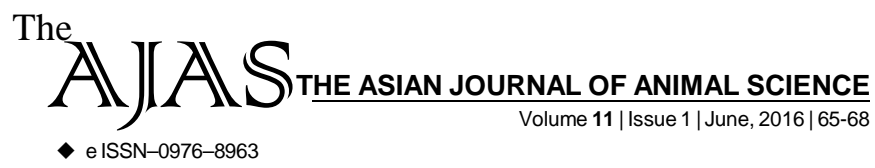

DOI : 10.15740/HAS/TAJAS/11.1/65-68 Visit us | www.researchjournal.co.in $\mathbf{S}$

A REVIEW

\title{
An overview of constraint analysis for improvement of dairy farming profession in India
}

\begin{abstract}
AARTI BHATELE
AUTHOR FOR CORRESPONDING :

AARTI BHATELE

Department of Pathology,

College of Veterinary and Animal

Sciences, Sardar Vallabh Bhai

Patel University of Agriculture

and Technology, MEERUT (U.P.)

INDIA

Email: draartivet@gmail.com
\end{abstract}

\begin{abstract}
Strategic planning of various projects and schemes regarding dairy farming made India, a top milk producer of the world. The history of these projects is very inserting and important for future planning to achieve new benchmarks in dairy sector. Since, India lags behind in global trade of milk and milk products, the different constraints of dairy farming in various regions of India need to take care of in order to enhance desired growth and economy in dairy sector.
\end{abstract}

KEY WORDS...... Dairy farming, Milk, Milk products, Projects

HOW TO CITE THIS ARTICLE - Bhatele, Aarti (2016). An overview of constraint analysis for improvement of dairy farming profession in India. Asian J. Animal Sci., 11(1): 65-68 (DOI : 10.15740/ HAS/TAJAS/11.1/65-68).

ARTICLE CHRONICLE - Received : 15.02.2016; Accepted : 24.05.2016 